\begin{tabular}{|c|c|}
\hline & MAGYAR GERONTOLÓGIA \\
3 & 13. ÉVFOLYAM 40. SZÁM \\
On-line verzió: ISSN 2062-3690 \\
www.https://ojs.lib.unideb.hu/gerontologia
\end{tabular}

\title{
A TELEMEDICINA SZOLGÁLTATÁS TÉRHÓdÍTÁSA A PANDÉMIA IDEJÉN
}

\section{Paulikné Varga Barbara}

Debreceni Egyetem Egészségügyi Kar

Debreceni Egyetem Ihrig Károly Gazdálkodás- és Szervezéstudományok Doktori Iskola

Kulcsszavak: telemedicina, pandémia, internethasználat, egészségügyi ellátás

\begin{abstract}
Absztrakt
A COVID világjárvány idején az info- és telekommunikáció szerepe az egészségügyi ellátásokban különösen felértékelődött. A kapcsolattartás alternatív módját tették lehetővé az orvos és páciense között az online kommunikációs formák és a mindennapi használtban elterjedt eszközök azokban az esetekben, amikor nincs feltétlenül szükség közvetlen személyes találkozásra, illetve a vészhelyzetben megelőzheti a szükséges személyes találkozást a távkonzultáció. Ebben a szituációban újszerü felelősséget és etikai terhet jelent az orvos számára a diagnosztizálás. Ezt ugyan könnyíthetik a laboratóriumi, a képalkotó diagnosztika korábban elkészült leletei, a közvetlen kommunikációt teremtő online rendszerek, de egy új diagnózis kialakításának vannak érzékeléssel megerősíthető feltételei is. A koronavírus okozta pandémia idején az alap- és járóbeteg ellátó rendszerben a járvány megfékezése céljából központi protokoll ajánlására - a személyes orvos-beteg találkozások számának minimalizálására törekedtek. Azokban az esetekben, ahol már korábban kialakult egy személyes kapcsolat az orvos és a beteg között, ismert a beteg kórtörténete, és kénytelenek a telemedicinát használni, éppen a legjobb értelemben vett hivatásukat gyakorolják. A
\end{abstract}


telemedicina hasznosságát a pandémia idején bizonyította, további fejlesztése nagy kihívás mind az informatika, mind az orvostudomány számára.

Keywords: telemedicine, pandemic, internet use, health care

\begin{abstract}
During the pandemic, the role of information and telecommunications in health care became particularly important. An alternative way of communicating between the doctor and his/her patient has been through online forms of communication and the tools commonly used in everyday cases where a face-to-face meeting is not absolutely necessary, or in an emergency, a face-to-face meeting may be preceded by a remote consultation. In this situation, diagnosis is a huge responsibility and an ethical burden for the physician. Although this can be facilitated by the findings of the laboratory, the previously completed imaging diagnostics, and the online systems that create direct communication, there are also conditions for the development of a new diagnosis that can be confirmed by perception. During the coronavirus pandemic, efforts were made to minimize the number of personal doctor-patient encounters in the primary and outpatient care systems to curb the epidemic, in order to curb the epidemic. In cases where a personal relationship between the doctor and the patient has already been established, the patient's relationship between the doctor and the patient has already been established, the patient's medical history is known and they are forced to use telemedicine, they are practicing their profession in the best sense. The usefulness of telemedicine during the pandemic has been demonstrated, and its further development is a major challenge for both informatics and medicine.
\end{abstract}

\title{
A telemedicina fejlődése
}

A telemedicina, amely a gyógyítás alternatív lehetőségét kínálja, az infokommunikációs eszközök terjedésével párhuzamosan fejlödött és bővül napjainkban is. Emellett azokon a területeken kezdték alkalmazni, ahol orvoshiány van vagy rendkívüli helyzet alakult ki. Így érthető, hogy a távdiagnosztikai területe rendelkezik a legnagyobb múlttal, szinte az internet terjedésével egyidejüleg alakult ki. Ma már mondhatni, minden kontinensen beépítették a gyakorlatba az első formáját, a távoli leletezést, és ezáltal Európában, Ausztráliában, ÉszakAmerikában, Dél- Afrikában is nagy népszerüségnek örvend (Daragó és tsai, 2013). Ezzel a nemzetközi szinten elfogadott megoldással, akár interaktív kapcsolattal a nagy távolságokat 
vagy épp az orvoshiányt lehetet úgy leküzdeni, hogy elkészülhet a beteg lelete, és akár orvos nélkül is elkezdődhet a gyógykezelése. Ehhez társul az is, hogy a távoli földrészek radiológusai közremüködésével oldják meg képalkotó diagnosztikai leletek (röntgen, ultrahang, stb,) gyors és szakszerü elkészítését. A távleletezés gyakorlata már Magyarországon is több éves múlttal rendelkezik, hiszen a radiológus szakemberhiány miatt nem lehet másképpen megoldani a problémát. (net1; net2; net3) A telemedicina másik területe a távmanipuláció, amikor a beavatkozást végző személy távolról végzi a vizsgálatot vagy beavatkozást. Ebben a két esetben a beteg bár jelen van a telemedicina alkalmazásakor, de nem igényel tőle aktív tevékenységet. Mindeközben a távkonzílium és telemonitoring alkalmazása aktív betegoldali közremüködést, együttmüködést vár el. A távkonzílium első alkalmazása több, mint egy évszázada történt. 1920. november 8-án, a tengeren dolgozó hajóorvosoknak biztosítottak konzíliumi támogatást a New York-i Seamen's Church Instituteben (Daragó és tsai 2013). A világürben lévő ürhajósok vitális paramétereit, pulzusát, vérnyomását telemetria segítségével figyelik az ürközpontokban, és szükség esetén már megoldottak távolról végzett beavatkozást is. A távkonzílium vagy szupervízió esetében a távdiagnosztikához hasonlóan a diagnózis felállításán túl, a beteggel egyeztetve a kezelés folyamatának meghatározására is sor kerülhet. Magyarországon a telemedicinális ellátás elterjedése a közfinanszírozott ellátásban a COVID pandémia előtt nem részesült nagy elfogadottságban.

A tradicionális orvoslásban meghatározhatóak azok az ellátási események, illetve azok részei, amelyekhez nem szükséges a közvetlen orvosi, egészségügyi szakdolgozói jelenlét, ezáltal csökkenthető az infrastruktúra igénybevétele, más esetekben az egészségügyi szakemberek azonban jogosan ragaszkodnak a személyes orvos-beteg találkozáshoz. Ez alól talán csak a háziorvosi ellátás képez kivételt, ahol bár kimondatlanul, de elfogadott lett a személyes jelenlét nélküli, akár a gondozói hálózat dolgozója általi gyógyszerfelírás. A pandémia hatalmas pozitív változást idézett elő az e-Health szolgáltatások alkalmazásában. Hatására a 2017-ben bevezetett Elektronikus Egészségügyi Szolgáltatási Térben alkalmazott eszolgáltatások igénybevétele is elfogadottá vált. A lakosság egészségügyi ellátatlansága okán 2020. szeptemberében változás következett be. 2012-ben még a telemedicina szolgáltatások elterjedésének egyik aggályaként szerepelt, hogy bár a nehéz anyagi körülmények között tevékenykedő intézmények számára hatékonyabb lenne a betegek ilyen módszertanú ellátása, azonban az $\mathrm{OEP}^{1}$ finanszírozás elmaradása miatt nem voltak motiváltak a telemediciniális ellátás bevezetésében (Ficzere, 2012).

${ }^{1}$ OEP- Országos Egészségbiztosítási Pénztár 
8 évvel később, a koronavírus járvány hatására az $\mathrm{EMMI}^{2}$ rendelete tette lehetővé a telemedicinális ellátás tényleges elterjedését. A járóbeteg szakellátás területén csak meghatározott beavatkozáskódokra $\left(\mathrm{OENO}^{3}, \mathrm{WHO}^{4}\right)$ terjesztették ki a telemedicinális ellátás lehetőségét. A háziorvosi ellátásban a gyógyszerfelírás, tanácsadás, konzultáció, betegirányítás, beutaló megírás, beteggondozás és rehabilitációs tevékenység esetén alkalmazható az ellátás okaként feltüntethető telemedicinális ellátás (157/2020. (IV. 29.) Korm. rendelet, EMMI).

A különböző felhasználási lehetőségek és az előjegyzési protokoll bevezetése megnövelte az orvosok telefonhívásainak gyakoriságát, a rendelési idő leterheltségét. A telemedicinális ellátás bevezetése mégis nagy előrelépést jelentett a korábbi időszak módszertanához viszonyítva, de nem szabad megfeledkezni a hátrányairól sem. A kezelőorvos úgy határoz meg diagnózist és terápiát, hogy nem tud fizikálist státuszt felmérni, csak a beteg által elmondottak jelenthetnek támpontot. Ennek feloldására lenne alkalmas a telemonitoring. A telemonitoringos megoldások általában nem egy megoldást vagy terméket népszerüsítenek, hanem az adott beteg által a beküldött, és adatbázisban összegyüjtött értékeket egy orvos, vagy egészségügyi dolgozó elemzi, és szükség esetén azonnali vagy igény szerinti visszajelzést ad. (net4) Ezen információk birtokában már a kezelőorvos is magabiztosabban alkothat véleményt a beteg egészségi állapotáról.

A személyes információkhoz azonban nem juthat hozzá bárki, annak védelmét is biztosítani kell, amihez mindenképpen szükség van a betegek és az egészségügyi szakdolgozók adatkezelési és adatvédelmi oktatására, valamint a technológiai továbbképzésre (net5). Megállapítható, hogy nem minden betegség esetén alkalmazható ez a módszer, de mára már megkerülhetetlenné vált. (Daragó és tsai. 2013)

A telemedicina a jelenlegi járvány idején már bizonyította életképességét, nagyrészt az ügyintézés, a szervezés, a nyilvántartás adminisztrációjában, de jelentős eredményeket mutatott fel a hatékony gyógyításban is.

Fejlődni azonban csak akkor tud, ha a betegek adminisztrációja olyan mértékben kiterjeszthető, hogy a kórtörténetüket, az alkalmazott terápiákat a gyógyítási ellátásának minden fázisában meg lehessen ismerni, azt ellenőrizni lehessen. Az ilyen rendszerek informatikai kiépítése, hozzáférhetősége, biztonsága, és a differenciált felhasználási módok, jogosultságok kiépítése egyszerre kíván az informatikai háttér fejlesztésén dolgozóktól hardver és szoftver újításokat. Ráadásul nemzetközi kompatibilitást is érvényesíteni kell, amit a pandémia kezelése különösen

\footnotetext{
${ }^{2}$ EMMI- Emberi Erőforrások Minisztériuma

${ }^{3}$ OENO- Orvosi Eljárások Nemzetközi Osztályozása

${ }^{4}$ WHO-World Health Organization
} 
aktuálissá tett. A munkájuk sikere viszont elképzelhetetlen az egészségügy szakmai szempontjainak az érvényesítése nélkül. Ma már különféle adatbázisokat használnak a gyógyításban, például a betegségek kódolt rendszerét a gyógyszerek rendszerének korrelációjával együtt kiépítették. Ettől összetettebbek azok a betegadminisztrációs rendszerek, amelyek személyesen a $\mathrm{TAJ}^{5}$ számuk alapján nyilvántartott betegekhez kapcsolódnak. A Debreceni Egyetem erre a feladatra szerveződő szakmai csoportja - szinte „percekkel”a pandémia előtt - bevezette UDMED néven a betegadminisztrációs rendszerét. A dolgozókkal történő megismertetésben magam is részt vettem, részben jelenléti oktatással, részben online oktatási segédanyag kidolgozásával.

A következőkben röviden vázolom a legismertebb adminisztrációs rendszerek felhasználási területeit.

\section{A betegadminisztrációs rendszerek}

A ma ismert egészségügyi információs rendszerek rendkívüli változáson mentek keresztül az elmúlt közel 30 évben. A Homogén Betegség Csoport (HBCs) szerinti finanszírozás 1993-as bevezetése elképzelhetetlen lett volna a kórházi információk gyüjtésére alkalmas GYÓGYINFOK ${ }^{6}$-os program nélkül. A kor technikai eszközei mellett elsődlegesen a finanszírozási adatok rögzítése, feldolgozása volt a követelmény, de a rendszerfejlesztők rámutattak az egészségügyben rejlő lehetőségekre, az adatelérés elengedhetetlenségére és az egészségügyi informatikai szakma létjogosultságára. Először elszigetelt, szakma- és/vagy betegségspecifikus betegnyilvántartó rendszerek jöttek létre, melyeket már azok a rendezett adatbázisok és az azokat kezelő kórházi információs rendszerek követték, amelyek a megfelelő helyen, megfelelő időben biztosítani tudták az arra jogosult személy számára az információhoz való hozzáférést (Kékes, Surján, Balkányi, \& Kozmann, 2000). Az egészségügyi információs rendszerek létrehozásán túl további fontos feladat a kvantitatív orvosi adatok rögzítése, tárolása, továbbítása. Az orvosi mérések eredményei nélkül ma már elképzelhetetlen volna a gyógyítási tevékenység, ezért is fontos az információhoz való hozzáférés biztosítása elsődlegesen az orvos szakma, másodlagosan a lakosság számára.

Az egészségügyi elektronikus informatikai háttér-rendszer (eHealth), ahol minden páciens adatai egy központi adatbázisba kerülnek - természetesen törvényben megszabott keretek között. Az adatokhoz - a megfelelő jogosultságok birtokában - a kezelőorvosok bárhonnan

\footnotetext{
${ }^{5}$ TAJ- Társadalombiztosítási Azonosító Jel

${ }^{6}$ GYÓGYINFOK- Gyógyító Ellátás Információs Központ
} 
hozzáférhetnek, így például nem okozhat gondot, ha a beteg valamiért nem tudja magával vinni korábbi leleteit.

Az egészségügyi ellátásban először a kórházi információs rendszerekben jelentek meg azok az infokommunikációs eszközök, amelyek alapot jelentenek a telemedicina elterjedésének. A telemedicina használatának alapvető feltétele a 2017-ben bevezetett Elektronikus Egészségügyi Szolgáltatási Tér (EESZT), amelyhez első körben a háziorvosi szolgálatok, járó- és fekvőbetegellátó intézmények és az összes gyógyszertár csatlakozott. Az EESZT egy olyan központi információs rendszer és adatbázis, amelyben a páciens engedélye alapján bárhonnan elérhetőek a kezelőorvos által szükségesnek tartott adatok. (Kékes, Szegedi, \& E. Kiss, 2018) 2018 őszén az Országos Mentőszolgálat, 2021 szeptemberében a gyógyászati segítőeszköz forgalmazók váltak csatlakozásra kötelezetté (net6). Az előzetes várakozásokkal ellentétesen az EESZT magánszolgáltatókra történő kiterjesztése lehetővé tette azt a szakmailag alátámasztott igényt, hogy az infokommunikációs hálózatokat a köz- és magánszolgáltatók közösen használhatják (Dózsa \& Ruzsovics, 2019). A szakmailag megfelelően HISA ${ }^{7}$ konform módon gyüjtött adatok pozitív tulajdonsága, hogy az Elektronikus Egészségügyi Szolgáltatási Térben lévő adatok megbízhatósági problémája fel sem merül.

\section{Az idősek helyzete a rendkívüli egészségügyi ellátás igénybevétele során}

A COVID pandémia első hullámában a legnagyobb működési problémát az idős orvosok kiemelése jelentette az ellátórendszerbl. Papp Magor értekezésében olvasható, hogy háziorvosi körzettípusonként 2007 és 2017 között 13,9\%-kal nőtt a 65 éves, illetve annál idősebb háziorvosok száma. A vizsgált időszakban körzettípusonként 3,7 és 5,4 között nőtt a háziorvosok átlagéletkora. A vegyes körzetekben 56,4 év, a felnőtt körzetekben 57 év, míg a gyermek körzetekben 59,5 év volt az átlagéletkor a 2017. január 1.-i adatok alapján (Papp, 2021). Az orvoshiány és az elvesztésüktől való aggodalom mellett az orvosokra jellemző hivatástudat és a tenni akarás okán viszont az idős orvosok elvállalták a telefonos kapcsolattartást, valamint azon betegek ellátását, akik nem a Covid-vírus miatti ellátást igényeltek.

A Nemzeti Média és Hírközlési Hatóság (NMHH) megbízásából 2017. októberében végzett reprezentatív felmérés alapján megállapításra került, hogy a háztartások 93\%-a rendelkezett mobiltelefonnal, s ezek kétharmada már 4 évvel ezelőtt okostelefon volt. Nagyon fontos megállapítás, hogy a fiatalok (91\%) és aktív korú lakosság (81\%) adatait figyelembe véve a

\footnotetext{
${ }^{7}$ HISA- Healthcare Information System Architecture
} 
legnagyobb növekedést a 60 év feletti lakosság körében találták, közöttük a legalább hetente internetezők száma egy év alatt 31\%-ról 41\%-ra növekedett (net7). Ez az érték a pandémia időszakában tovább emelkedett, amelyekről ma még legfeljebb a kereskedelmi statisztikákból vannak becsléseink, de már a nemzetközi és hazai szakirodalom, az NMHH 2017. évi felmérése is arra a következtetésre ad lehetőséget, hogy az idős lakosság is egyre fogékonyabb az okostelefonok és Small screen technológiák felhasználására, alkalmazására. Ezzel együtt azt is fontos hangsúlyozni, hogy az idős kor időt és lehetőséget nyújt az önképzésre, az új lehetőségek felfedezésére (Bene, Móré \& Zombory, 2020). Az új technológiák, eszközök iránti hajlandóságot és fogékonyságot szimbolizálja az is, hogy az NMHH 2020. évi felmérésében a megkérdezettek 52\%-a nyilatkozta, hogy a családi kapcsolattartásra - akadályoztatásuk eseténvideohívást kezdeményeznek. Az akadályoztatás és a fertőzésektől való félelem a pandémia alatt fokozottabban érvényesült. A betegek a telemedicina előnyeként említik ezen kívül, hogy kisebb mértékü munkahelyi, illetve időbeni kiesést okoz, és az utazási költség is elmarad. Az egészségügyi intézmények számára a hatékonyságnövelés, valamint az idős, egyedülélő betegek egészségi állapotának naprakész nyomon követése jelenti a legfőbb pozitívumot.

A leírt tendenciák nyomán elmondható, hogy nemcsak az aktív korú lakosság, de az idősek számára is sok esetben megoldást jelenthet a telemedicinális ellátás, egy videohívás lebonyolítása a kezelőorvosával. Világviszonylatban az mHealth applikációk egyharmadát a mentális egészség, 15\%-át az endokrin betegségek, 10\%-át a szív és érrendszeri betegségek monitorozására hozták létre. Megállapításra került az is, hogy ezen telemedicinális szolgáltatásokat az uniós tagállamok tekintetében leginkább Németországban és az Egyesült Királyságban alkalmazzák, ezzel együtt az került megállításra, hogy az egy lakosra jutó telehealth szolgáltatásból befolyó bevétel a Skandináv országokban a legmagasabb. (net4). A lakosság szempontjából a vezető morbiditási és mortalitási betegségek, mint a szív- és érrendszeri, a krónikus obstruktív tüdőbetegség és a cukorbeteg alapellátásban lévő gondozása jelentené a megoldandó feladatot. Habár az egyes világrészekben eltérő mértékben, de a WHO adatai alapján a 25 év feletti lakosság átlagosan 40\%-a szenved hipertóniában. (Kékes, Szegedi, \& E. Kiss, 2018) A gyakoriság alapján indokoltan a hipertónia gondozása volt az első a telemedicina terjedése szempontjából. A hatékonyabb gondozása érdekében már a 2000-es évektől egyre kiterjedtebben alkalmazták az otthoni vérnyomásmérésre az elektronikus mérőeszközöket (szenzor), amelyek az okostelefonok, tabletek megjelenésével már közvetlen kapcsolódtak az adatgyüjtő központokhoz. Hazai és nemzetközi szakirodalmi adatok alapján az otthoni vérnyomásmérés és a telemonitoring alkalmazása egyaránt javítja a beteg adherenciáját, 
az antihipertenzív kezelés eredményességét és csökkenti a túlkezelés kockázatát (Kiss\&Kékes, 2012; Parati, Omboni \& Ambini, 2009).

A krónikus pangásos szívelégtelenség a telemedicinális eszközökkel legalaposabban vizsgált terület (Kékes, Szegedi, \& E. Kiss, 2018). Clarke és munkatársai (2011) 3-15 hónap követési idővel, 3480 főre kiterjedő vizsgálatának alapján megállapították, hogy a beteg egészségi állapotának monitorozásával, a szakszemélyzet támogatásával és a nővérek otthoni látogatásával szignifikánsan csökkent a halálozás és a kórházi felvételek száma..Említésre méltó az Olaszországban, Lombardia területén elindult TELEMACO (TELEMedicina Ai piccoli COmuni lombardi) projekt, ami egy infrastrukturálisan elmaradottabb mezőgazdasági vidéken nyújt teljeskörü otthoni telemedicinális ellátást krónikus pangásos szívelégtelenségben szenvedő betegek számára (Schmidt, Schuchert, Krieg, \& Oeff, 2010) .

A diabetes mellitus esetén a telemedicinális ellátás jelentős mértékben megkönnyítheti az azonnali beavatkozás lehetőségével a beteg kezelésének és gondozásának sikerességét, példa lehet a beteg által gyüjtött mérési adatok alapján beállított gyógyszeradagolás szabályozása (Kékes, Szegedi, \& E. Kiss, 2018).

Ezek a telemedicinális megoldások hatékonyan segíthetnék a Magyarországon betöltetlen háziorvosi praxisokkal rendelkező vidéki területeken élő lakosság egészségügyi ellátását. A szolgáltatások szempontjából nem cél a teljes idejű, a „24/7/365” állapot elérése, de már a törődést mutatja a lehetőség, hogy szükség esetén az összegyüjtött, feltöltött adatokat a kezelőorvos megnézheti.

\section{A telemedicina és a pandémia kölcsönhatásai}

Elsősorban az időskorú, krónikus betegek egészségi állapotának folyamatos nyomon követésére és védelmének érdekében szinte egyetlen mód a telemediciniális eszközök használata. Ezek közé soroljuk a vészjelző berendezéseket, az egyszerü és az okos telefonokat is, bár ezek csak a figyelmeztetést, a kikérdezést teszik lehetővé, sokszor így is életet menthetnek. Az orvosi ellátás aspektusából a telemedicinális egészségügyi ellátás összetettebb, az anamnézis, a státusz, a diagnózis, a terápia meghatározásából áll. Ehhez a vizsgálathoz ellátás esetén elöre megkérhetjük a beteget, ha állapota engedi, hogy müködjön közre, például mérje meg a gyógyszerfelírás esetén a vérnyomását, vércukorszintjét, ha nem ezt tesszük, akkor nem beszélhetünk státusz-meghatározásról, ami az ellátás alapfeltétele.

A közeljövőben - a fejlesztés érdekében, úgy vélem - az ellátórendszernek a jelenlegi leterheltsége mellett, ki kell alakítania a szolgáltatási térben egy olyan egészséginformatikai megoldást, amely során a mesterséges intelligenciát igénybe véve, alkalmazva, legalább a 
súlyos állapotú betegek egészségi állapotát nyomon lehetne követni. A jelenlegi helyzet javítására szolgáló intézkedések bevezetése egyre sürgetőbb, hiszen már csaknem két éve élnek úgy emberek ${ }^{8}$, hogy csak telefonon, e-mailen tartják a kapcsolatot az orvosukkal.

A telemedicinális ellátás előnye a hagyományos ellátással szemben az alacsonyabb erőforrásigény, azonban erősen korlátos az igénybevételi lehetősége. Másrészt előfordulhat, hogy nemcsak mentális állapotuk romlása miatt nem javulnak a külvilágtól elzárt emberek, hanem a diagnosztizálásuk nem elég sikeres. Gondoljunk bele, hogy az otthonuk elhagyása nélkül, olyan vitális paraméterek hiányával kell az orvosoknak az állapotukról dönteni, amelyek a telemedicina módszereinek a fejlesztésével pótolhatóak lennének. Már most is jelentős előnyt adnak az okosórák, az okostelefonok, amelyeknek az egészséggel kapcsolatos applikációin megjeleníthetőek a telemonitoring alkalmazások, és a vitális paraméterek gyüjtésével akár életet is menthetnek, de ezek használata még nem nevezhető általánosnak épp a legveszélyeztetettebb rétegekben.

Végezetül kijelenthetjük, a telemedicina nem szoríthatja ki a személyes orvoslást, de sokszínüvé, gyorsabbá, hatékonyabbá teheti olyankor is, amikor nincs világjárvány.

\section{Felhasznált irodalom}

Bene, Á., Móré, M., \& Zombory, J. (2020). A digitalizáció néhány elemének időseket érintő hatásai-Karantén előtti helyzetkép, Magyar Gerontológia, 29-51.

Daragó, L., Jung, Zs., Ispán, F., Bendes, R., \& Dinya, E. (2013). A telemedicina előnyei és hátrányai, Orvosi hetilap, 1167-1171

Dózsa, C., \& Ruzsovics, Á. (2019). A telemedicina nemzetközi helyzetismertetése és a hazai telemedicina program szabályozási és finanszírozási kihívásai, II. rész. IME, 5-10.

Ficzere, A. (2012). Telemedicina szolgáltatás bevezetéséhez szükséges lépések. IME.

Kékes, E, Surján, Gy., Balkányi, L., \& Kozmann, Gy. (2000). Egészségügyi informatika, Medicina Könykiadó Rt, Budapest

Kékes, E., Szegedi, J., E. \& Kiss, I. (2018). A telemedicina szerepe a beteg-orvos, betegalapellátás, beteg-szakellátás kapcsolat optimális megoldása érdekében. IMEInterdiszciplináris Magyar Egészségügy, 24-33.

\footnotetext{
${ }^{8}$ Jelen cikk megjelenéséhez képest (2021. december)
} 
Kiss, I., \& Kékes, E. (2012). A hipertóniás betegek célvérnyomáselérési arányának és gondozási minőségének segítése telemedicinális lehetőségek alkalmazásával. Hypertonia és Nephrologia, 243-5.

Papp, M (2021). A háziorvosi ellátás humánerőforrás krízise Magyarországon longitudinális vizsgálat tükrében. Debreceni Egyetem Egészségtudományok Doktori Iskola

Parati, G., Omboni, S., \& Ambini, F. (2009). Home blood pressure telemonitoring improves hypertension control in general practice. The Tele BP Care study. Journal of Hypertension, 198-203.

Schmidt, S., Schuchert, A., Krieg, T., \& Oeff, M. (2010). Home telemonitoring in patients with chronic heart failure: a chance to improve patient care? . Deutsches Arzteblatt Internationa, $131-138$

\section{Internetes hivatkozások}

net1: https://www.telemedicineclinic.co.uk/about-tmc/, letöltés: 2021.10.19

net2:

https://mok.hu/hirek/lapszemle/most-radiologushiany-miatt-van-veszely-ahonvedkorhazban, letöltés: 2021.10.19

net3: https://immedicare.co.uk/our-services/, letöltés: 2021.10.20

net4: https://ec.europa.eu/health/sites/default/files/ehealth/docs/2018_provision_marketstudy_ telemedicine_en.pdf

net5: Kaspersky_Healthcare-report-2021_eng.pdf (kasperskycontenthub.com), letöltés: 2021.11.20.

net6: Lakosság - EESZT Információs portál (gov.hu), letöltés: 2021.11.20

net7: https://nmhh.hu/dokumentum/195102/lakossagi_internethasznalat_2017.pdf, letöltés: 2021.10.20 


\section{A Szerző:}

\section{Paulikné Varga Barbara}

ORCID: 0000-0001-9217-0135

tanársegéd, Debreceni Egyetem Egészségügyi Kar Egészségtudományi Intézet, Egészségügyi Informatikai nem önálló Tanszék 4400 Nyíregyháza Sóstói u. 2-4.

PhD hallgató, Debreceni Egyetem Társadalomtudományi Doktori Tanács Ihrig Károly Gazdálkodás- és Szervezéstudományok Doktori Iskola 